A lipoprotein complex may be of common occurrence in naturally tanned structures. In both the cockroach ootheca and in the blowfly puparium, I have clearly demonstrated a lipoid to be present throughout the whole thickness of the tanned regions. Furthermore, lipoids have been reported in the exocuticle of Myriapods. It will be of interest to learn whether lipoids are associated with proteins in other tanned structures.

A full account of this and other aspects of the present work will be given elsewhere. My thanks are due to Prof. R. Dennell for his interest and criticism.

Department of Zoology, University,

Manchester 13. April 28.

${ }^{1}$ Dennell, R., Nature, 184, 370 (1949)

2 Brown, C. H., Nature, 165, 275 (1950)

3 Pryor, M. G. M., Proc. Roy. Soc., B, 128, 378 (1940)

4 Dennell, R., Proc. Roy. Soc., B, 134, 79 (1947).

5 Blower, G., Nature, 165, 569 (1950).

'Wigglesworth, V. B., Proc. Roy. Soc., B, 134, 163 (1947).

? Blower, G., Quart. J. Mic. Sci., 92, 141 (1951).

a Pryor, M. G. M., Proc. Roy. Soc., B, 128, 393 (1940).

\section{Packed Red-Cell Volume in the Tropics}

$I_{T}$ was found that when men stayed in airconditioned rooms at about $30^{\circ} \mathrm{C}$. for a few days their packed red-cell volume fell ${ }^{1,2}$. A rise in this value was likewise found in conditions of low environmental temperature ${ }^{2}$. More prolonged exposure to conditions of high environmental temperature caused by change of season was also associated with a fall in the packed red-cell volume ${ }^{3}$. No satisfactory information about the physiological effect on the packed red-cell volume of people living for several months or years in a warm climate could be found in the available literature. The results of an investiga tion made in Singapore may, therefore, be of interest.

The subjects were healthy, well-nourished men and women of different races (see table) who had lived in the tropics for at least six months, and they were all between twenty and forty years old. Samples of venous blood were collected with minimal stasis, and an ammonium and potassium oxalate mixture used as an anti-coagulant". Estimations of the packed redcell volume were made by means of Wintrobe hæmatocrit tubes ${ }^{5}$ which were eentrifuged for $1 \mathrm{hr}$. at 3,000 r.p.m.

PACKED RED-CELI VOLUME OF NORMaI MEN AND WOMEN IIVING IN SINGAPORF

\begin{tabular}{|c|c|c|c|c|}
\hline Racial group & No. & $\underset{\text { (per cent) }}{\text { Mean }}$ & S.D. & $\begin{array}{l}\text { S.E. of } \\
\text { mean }\end{array}$ \\
\hline $\begin{array}{l}\text { Men } \\
\text { Chinese }\end{array}$ & 73 & $47 \cdot 69$ & 6.513 & 0.7622 \\
\hline $\begin{array}{l}\text { Indians and } \\
\text { others }\end{array}$ & 58 & $47 \cdot 59$ & $7 \cdot 266$ & 0.9541 \\
\hline European & 121 & $47 \cdot 02$ & 5.420 & 0.4927 \\
\hline Women & & & & \\
\hline $\begin{array}{l}\text { Europeans } \\
\text { Asians } \\
\text { All females }\end{array}$ & $\begin{array}{l}57 \\
21 \\
78\end{array}$ & $\begin{array}{l}40 \cdot 56 \\
41 \cdot 43 \\
40 \cdot 80\end{array}$ & $\begin{array}{l}6 \cdot 060 \\
9 \cdot 824 \\
5 \cdot 429\end{array}$ & $\begin{array}{l}0 \cdot 8025 \\
2 \cdot 1440 \\
0 \cdot 6146\end{array}$ \\
\hline
\end{tabular}

The mean packed red-cell volume of 252 men was $47 \cdot 35$ per cent, and that of 78 women $40 \cdot 80$ per cent. Details are given in the table. The differences between the mean value for each racial group were not statistically significant by the $t$ test $^{6}$.
The present findings are slightly higher than those found in temperate climates ${ }^{7}$. The results of this investigation suggest that living in a warm environment for several months or years is not associated with a fall in the packed red-cell volume. The fall in this value found in men during shorter conditions of exposure to heat ${ }^{1-3}$ appears to have been a temporary change. Recovery of the packed red-cell volume might provide objective evidence of complete acclimatization.

Department of Physiology,

G. R. WADSWORTH

University of Malaya,

Singapore 3.

May 12.

${ }^{1}$ Bazett, H. C., Sunderman, F. W., Doupe, J., and Scott, J. C., Amer. J. Physiol., 129, 69 (1940).

2 Glaser, E. M., J. Physiol., 110, 330 (1949).

${ }^{3}$ Maxfleld, M. E., Bazett, HI. C., and Chambers, C. C., Amer. J. Physiol., 133, 128 (1941).

4 Heller, V. G., and Paul, H., J. Lab, Clin. Med., 19, 777 (1933).

${ }^{5}$ Wintrobe, M. M., J. Lab. Clin. Med., 15, 287 (1929).

"Wisher, R. A., "Statistical Methods for Research Workers" (London : 10th edit., 1948).

${ }^{7}$ Gram, H. C., and Norgaard, A., Arch. Int. Med., 31, 164 (1923). Walters, O. S., Amer. J. Physiol., 110, 37 (1934). Price-Jones, P., Vaughan, J. M., and Goddard, H. M., J. Path. Bact., 40, 503 (1935). McGeorge, M., J. Path. Bact., 42, 67 (19s6). Donelson, J., Leichsenring, J. M., and Ohlson, M. A., Amer. J. Physiol., 138, 626 (1943). Lange, H., and Palmer, H., Acta Med. Scand., 127, 1 (1947)

\section{Reversal of the Heart-beat in Tunicates}

TrE mechanism controlling the periodic reversal of the heart-beat in tunicates is still in dispute. Internal control has been thought to exist, and to be due either to local nerve centres ${ }^{1}$, or to physiologically differentiated areas of cardiac muscle ${ }^{2}$, at each end of the heart. Evidence from the action of drugs has been conflicting ${ }^{3}$. Hunter ${ }^{1}$ found a ring of cells around each end of the heart which he thought to be nerve cells, and Alexandrowicz ${ }^{4}$ described nerve fibres but was uncertain whether ganglion cells exist.

I have found rings of fusiform cells in the heart of Ciona intestinalis (L) which seem to correspond to those described by Hunter ${ }^{1}$, but they are connective tissue cells and not nerve cells, being the ends of sheets of connective tissue that line the large blood vessels at their cardiac junction. Von Skramlik ${ }^{2}$ found evidence for the existence at each end of the heart of a small area of cardiac muscle which initiates the beats; alternating dominance of one area over the other would produce periodic reversal. Lahille ${ }^{5}$ believed that certain parts of the peripheral system are unable to accept blood as quickly as the heart supplies it, and that the resulting back-pressure that is built up eventually stops the heart. When the heart starts to beat again, it does so in the opposite direction. Haywood and Moon ${ }^{6}$ have revived Lahille's theory and from it have formulated an equation relating the time of beating in one direction with the number of beats. In support of the theory they produced experimental results which satisfied the equation, and also they failed to observe reversal of isolated hearts, a phenomenon recorded by von Skramlik ${ }^{2}$.

Periodic reversal of isolated hearts, if it could be shown to occur, would be strong evidence against the back-pressure theory, since no such pressure can be built up in a heart not connected with its closed system of vessels. The heart was therefore removed from a number of specimens of Ciona and observed continuously for 6-12 hr. It was found that, in most 